Tropical Journal of Pharmaceutical Research August 2020; 19 (8): 1631-1636

ISSN: $1596-5996$ (print); 1596-9827 (electronic)

(C) Pharmacotherapy Group, Faculty of Pharmacy, University of Benin, Benin City, 300001 Nigeria.

\title{
Ginsenoside induces cell death in breast cancer cells via ROS/PI3K/Akt signaling pathway
}

\author{
Lihong $\mathrm{He}^{1}$, Xiaorui Wang ${ }^{1}$, Qing $\mathrm{Ma}^{2}$, Weipeng Zhao', Yongsheng Jia ${ }^{1}$, Guolei \\ Dong $^{1}$, Yuehong Zhu ${ }^{1}$, Xiaochen Jia ${ }^{1}$, Zhongsheng Tong ${ }^{1 *}$ \\ ${ }^{1}$ Department of Breast Cancer, Tianjin Medical University Cancer Institute and Hospital, ${ }^{2}$ Department of Oncology, General \\ Hospital of Tianjin Medical University, Tianjin, PR China \\ *For correspondence: Email: msst19@163.com
}

\begin{abstract}
Purpose: To study the influence of ginsenoside on breast carcinoma, and the mechanism of action involved.

Methods: Different concentrations of ginsenoside were used to treat MCF-7 breast cancer cell line. Cell viability was measured by MTT assay, while protein expressions of $p$-Akt and $p$-PI3K were determined using Western blotting. The concentrations of reactive oxidative reactants and reactive oxygen species (ROS) were assessed using fluorescence immunoassay and immunofluorescence assay. The mechanism of action involved in ginsenoside-mediated apoptosis was determined based on ROS/PI3K/Akt signaling pathway.

Results: There was no change in the inhibition of MCF-7 cell proliferation in control cells with time ( $p>$ 0.05). However, inhibition of MCF-7 cell proliferation in ginsenoside group was significantly higher than that in the control group ( $p<0.05)$; furthermore, it increased with time and ginsenoside concentration. Apoptosis was markedly and concentration-dependently higher in ginsenoside-treated MCF-7 cells than in controls $(p>0.05)$. There were lower protein levels of $p$-PI3K and $p$-Akt in ginsenoside-exposed MCF-7 cells than in control group; the protein expressions decreased with increase in ginsenoside concentration $(p<0.05)$. The expressions of ROS in ginsenoside-treated MCF-7 cells declined, relative to the untreated group; in addition, the expressions decreased with increase in ginsenoside concentration $(p<0.05)$.

Conclusion: Ginsenoside suppresses proliferation of MCF-7 cell line, and exerts apoptotic effect on the cells via inhibition of the ROS/PI3KJAkt signal pathway. This provides a new approach to treat breast cancer.
\end{abstract}

Keywords: Breast cancer cells, Ginsenoside, Apoptosis, ROS/PI3K/Akt signaling pathway

\begin{abstract}
This is an Open Access article that uses a fund-ing model which does not charge readers or their institutions for access and distributed under the terms of the Creative Commons Attribution License (http://creativecommons.org/licenses/by/4.0) and the Budapest Open Access Initiative (http://www.budapestopenaccessinitiative.org/read), which permit unrestricted use, distribution, and reproduction in any medium, provided the original work is properly credited.

Tropical Journal of Pharmaceutical Research is indexed by Science Citation Index (SciSearch), Scopus, International Pharmaceutical Abstract, Chemical Abstracts, Embase, Index Copernicus, EBSCO, African Index Medicus, JournalSeek, Journal Citation Reports/Science Edition, Directory of Open Access Journals (DOAJ), African Journal Online, Bioline International, Open-J-Gate and Pharmacy Abstracts
\end{abstract}

\section{INTRODUCTION}

Breast carcinoma is associated with mammary gland epithelial cells, and has become a serious threat to women's physical and mental health [1].
The etiology of breast cancer is not completely understood. However, recent studies have found that the incidence of breast cancer has a certain regularity, especially in women with high risk factors for the disease [2]. The common clinical 
symptoms of breast cancer are mass/lump in breast, nipple discharge, skin changes, areola abnormalities and axillary lymphadenoma [3].

Saponins, the major bioactive compounds in ginseng, have anti-aging, memory-enhancing, hepatoprotective, anti-tumor and antiinflammatory effects [4].

Ginsenoside is a saponin that has been reported to be effective against myocardial ischemia reperfusion injury, tumors, hyperglycemia, and liver diseases. Moreover, it exerts antiinflammatory effects. Although clinical findings have shown that ginseng saponin inhibits liver cancer, bladder cancer, nasopharyngeal carcinoma and colon cancer, and produced antiproliferative effects on various tumor cells, not much research has been carried out on its inhibitory effects on breast cancer cell proliferation, and the mechanism involved [5-7].

The purpose of the present investigation was to determine the apoptotic and anti-proliferative influences of ginsenoside on MCF-7 cells, as well as the mechanism involved.

\section{EXPERIMENTAL}

\section{Materials}

Human papillary carcinoma MCF-7 cells were purchased from Nanjing Kaiji Biotechnology Development Co. Ltd. Ginsenoside (purity > $98.0 \%$ ) was obtained from Chengdu Pulis Biotechnology Co. Ltd). Fetal bovine serum and DMEM were products of Hyclone Biological Company, USA, while MTT detection kits were purchased from AM-Resco, USA.

Apoptosis detection kits were bought from Shenzhen Jingmei Biological Engineering Co. Ltd. Phosphoglyceraldehyde dehydrogenase (GAPDH), p-PI3K, p-AKT and polyclonal antibodies were supplied by Santa Cruz, USA), while HRP-labeled $2^{\circ}$ antibody was product of Beijing Zhongshan Jinqiao Biotechnology Co. Ltd.

Carbon dioxide $\left(\mathrm{CO}_{2}\right)$ incubator was bought from HeraCell 150i, flow cytometer was obtained from BD Company), while 2-16R cryogenic highspeed centrifuge was product of Hunan Henuo Instrument Equipment Co. Ltd. Inverted microscope was bought from Olympus. Protein electrophoresis and transfer equipment, Mini Opticon fluorescence quantitative PCR, and Enzyme marker were products of Bio-Rad, (USA).

\section{Culturing of MCF-7 cells}

\section{Cell resuscitation}

The MCF-7 cells in cryopreserved tubes at -80 ${ }^{\circ} \mathrm{C}$ were thawed by placing them in a beaker at $37^{\circ} \mathrm{C}$. The thawed liquid in each storage tube was then transferred into a 15-ml centrifuge tube, using a pipette gun, and the tube was centrifuged at $800 \mathrm{rpm}$ for $5 \mathrm{~min}$. After centrifugation, $1 \mathrm{ml}$ of DMEM medium was put into the centrifuge tube and mixed with a pipette gun. The liquid from the centrifuge tube was aspirated into a cell bottle, and $3 \mathrm{~mL}$ of DMEM was added, followed by horizontal shaking. The surface of the cell bottle was wiped with alcohol-soaked cotton ball, and the cap of the cell bottle was loosened, followed by incubation of the cells in a $5 \% \mathrm{CO}_{2}$ incubator at $37^{\circ} \mathrm{C}$. After $6 \mathrm{~h}$, the cells were adherent to the wall, and the culture medium was refreshed.

\section{Cell exchange}

The old culture medium was replaced with $3 \mathrm{ml}$ of PBS, followed by vigorous horizontal shaking and removal of medium. This operation was repeated twice. Then, an appropriate amount of DMEM complete medium was added, and the cell bottle surface was wiped with alcoholmoistened cotton ball, followed by loosening of the bottle cap and incubation of the cells at $37^{\circ} \mathrm{C}$ in a $5 \% \mathrm{CO}_{2}$ incubator.

\section{Cell passage}

When the cell growth density was about $80-90$ $\%$, the old culture medium was discarded, and 3 $\mathrm{mL}$ of PBS was added, followed by horizontal shaking and discarding of medium. This was repeated thrice. Then, $10-14 \mathrm{~mL}$ of $0.25 \%$ trypsin was added to the remaining PBS in the stem cell bottle. The cell bottle was capped, and the bottle was shaken horizontally to ensure that the trypsin was evenly distributed at the bottom of the cell bottle.

The cell morphology was observed under the microscope, and digestion was stopped when the cells became round and bright. Then, trypsin was decanted and the lid was covered. Care was taken to ensure that the cells in the cell bottle were completely suspended in the medium. Then, $10^{-3} \mathrm{~L}$ of DMEM was put into the cell bottle. After mixing, $1 \mathrm{~mL}$ of the suspension was re-cultured in a fresh culture vial. An appropriate amount of DMEM was put into the two bottles, followed by incubation at $37^{\circ} \mathrm{C}$ in a $5 \% \mathrm{CO}_{2}$ incubator. Cell growth was observed $24 \mathrm{~h}$ later. 
Determination of the effect of ginsenoside on cell proliferation

At 80 - $90 \%$ confluence, the MCF-7 cells in good growth condition were subjected to digestion. Thereafter, they were plated in a 96-well plate at a concentration of 100 cells/well, and cultured for $24 \mathrm{~h}$ to make the cells completely adherent. After carefully pouring out the culture medium, $0.1 \mathrm{~mL}$ of new medium was added, prior to exposure to $0.02 \mathrm{~mL}$ of ginsenoside at different final concentrations of $30,60,90 \mu \mathrm{mol} / \mathrm{L}$ (cells without ginsenoside served as control).

The wells were cultured in $\mathrm{CO}_{2}$ incubator for 20 , 40 , and $60 \mathrm{~h}$. At the end of each time period, 20 $\mu \mathrm{L}$ MTT solution was added to each well, and the culturing was continued for $4 \mathrm{~h}$. Thereafter, the culture medium was carefully replaced with DMSO $(150 \mu \mathrm{L})$ to solubilize the formazan crystals. The optical density of each well was read at a wavelength of $490 \mathrm{~nm}$, and the percentage inhibition of cell proliferation was calculated.

\section{Determination of apoptotic effect of ginsenoside}

The MCF-7 cells at $80-90 \%$ confluence were digested. A volume of $2 \mathrm{~mL}$ of each well was inoculated into a 6-well plate and cultured for 24 $\mathrm{h}$ to make it completely adherent to the wall. After carefully discarding the culture medium, 1.8 $\mathrm{mL}$ of new culture medium was added, and 200 $\mu \mathrm{L}$ of ginsenoside of different concentrations (final concentrations $=30,60$ and $90 \mu \mathrm{mol} / \mathrm{L}$ ) were added, followed by culturing in $\mathrm{CO}_{2}$ incubator for $48 \mathrm{~h}$.

Cells without ginsenoside served as control. The cells were collected after tryptic digestion, and the concentration was changed to $5 \times 10^{5}$ cells $/ \mathrm{mL}$. Then, $1 \mathrm{~mL}$ of cell suspension was rinsed two times using PBS buffer. Then, $200 \mu \mathrm{L}$ of cells was re-suspended in buffer. In the dark, $10 \mu \mathrm{L}$ Annexin- $\mathrm{V}$ was added, and after $10 \mathrm{~min}, 5$ $\mu \mathrm{L}$ of pyridine iodide was added. After $5 \mathrm{~min}$, percentage apoptosis was measured using a flow cytometer.

\section{Assay of protein expressions of p-pi3k and p-} akt

After exposing the cells to different doses of ginsenoside for $48 \mathrm{~h}$, they were rinsed thrice with PBS, and lysed with appropriate cell lysis solution. Total protein content of the lysates was determined with BCA method. Then, $20 \mu \mathrm{g}$ of each sample was denatured and subjected to 12 $\%$ polyacrylamide gel electrophoresis. The protein bands were transferred to polyvinylidene membrane, and the membrane was incubated at $4{ }^{\circ} \mathrm{C}$ for $12 \mathrm{~h}$ with primary antibodies for $\mathrm{p}-\mathrm{PI} 3 \mathrm{~K}$, p-AKT and GAPDH, each at 1:500 dilution. Thereafter, the membrane was incubated with horse radish peroxide-linked $2^{\circ}$ antibody for $2 \mathrm{~h}$. Following electrochemical luminescence for color development and exposure, optical densities of the protein bands were read in gel-pro analyzer.

\section{Determination of ROS levels}

Following treatment of MCF-7 cells with ginsenoside at different concentrations for $48 \mathrm{~h}$, the cells were rinsed thrice with PBS, and incubated with $1 \mathrm{~mL}$ of $10 \mu \mathrm{L} / \mathrm{L}$ DCFH-DA at $37^{\circ} \mathrm{C}$ for $30 \mathrm{~min}$. Then, the cover slides were clamped with plastic forceps, placed on the slide, and placed on normal fluorescence microscope.

\section{Statistical analysis}

Statistical analysis was done with SPSS 20.0 software. Measurement data are presented as mean \pm SD. Two-group comparisons were carried out using $t$-test. Counting data are presented as \%, and were analyzed using $X^{2}$. Values of $p<0.05$ were taken as indicative of statistically significant differences.

\section{RESULTS}

\section{Effect of different doses of ginsenoside on viability of MCF-7 cells}

As shown in Table 1, in control MCF-7 cells, there were no changes in viability. However, the $\%$ proliferation inhibition of cells treated with ginsenoside was markedly higher, relative to untreated cells, and it increased with extension of time and increase in concentration.

Table 1: Effect of ginsenoside at different concentrations on proliferation of MCF-7 cells (mean \pm SD)

\begin{tabular}{|c|c|c|c|c|}
\hline \multirow{2}{*}{ Group } & \multirow{2}{*}{$\begin{array}{c}\text { Concentration } \\
(\mu \mathrm{mol} / \mathrm{L})\end{array}$} & \multicolumn{3}{|c|}{ Proliferation (\%) } \\
\hline & & $20 \mathrm{~h}$ & $40 h$ & $60 h$ \\
\hline Control & 0 & 0 & 0 & 0 \\
\hline Low ginsenoside & 30 & $13.26 \pm 1.05^{a}$ & $28.41 \pm 3.12^{a}$ & $35.18 \pm 3.20^{a}$ \\
\hline Medium ginsenoside & 60 & $26.95 \pm 3.26^{\mathrm{ab}}$ & $42.56 \pm 4.28^{\mathrm{ab}}$ & $56.84 \pm 5.08^{a b}$ \\
\hline High ginsenoside & 90 & $41.06 \pm 5.23^{\mathrm{abc}}$ & $58.46 \pm 6.38^{\mathrm{abc}}$ & $66.51 \pm 6.37^{\mathrm{abc}}$ \\
\hline
\end{tabular}


Effect of different concentrations ginsenoside on apoptosis of MCF-7 cells

Table 2 shows that \% apoptosis in ginsenosideexposed cells was markedly higher, relative to control cells, and it increased with increase in ginsenoside concentration.

Table 2: Effect of ginsenoside at different concentrations on apoptosis of MCF-7 cells (mean \pm SD)

\begin{tabular}{lcc}
\hline Group & $\begin{array}{c}\text { Concentration } \\
(\mu \mathrm{mol} / \mathrm{L})\end{array}$ & Apoptosis (\%) \\
\hline Blank & 0 & $3.21 \pm 0.21$ \\
Control & 30 & $21.31 \pm 2.16^{\mathrm{a}}$ \\
Low & 60 & $38.79 \pm 3.18^{\mathrm{ab}}$ \\
ginsenoside & 90 & $48.15 \pm 5.41^{\mathrm{abc}}$ \\
$\begin{array}{l}\text { Medium } \\
\text { ginsenoside }\end{array}$ & 90.05, vs with control; ${ }^{\mathrm{b} p}<<0.05 \mathrm{~B}$, vs low \\
\hline a $<$ 0.0 \\
$\begin{array}{l}\text { ginsenoside group; }{ }^{\mathrm{c}} p<0.05, \text { vs medium ginsenoside } \\
\text { group }\end{array}$
\end{tabular}

\section{Effect of ginsenoside at different} concentrations on $p$-pi3k and p-akt levels

Table 3 and Figure 1 show that there were marked downregulations of these proteins in cells treated with ginsenoside relative to untreated cells, they decreased with increase in ginsenoside concentration.

Table 3: Influence of ginsenoside at different concentrations on p-PI3K and p-AKT levels in MCF-7 cells (mean $\pm \mathrm{SD}$ )

\begin{tabular}{|c|c|c|c|}
\hline Group & $\begin{array}{c}\text { Concentration } \\
(\mu \mathrm{mol} / \mathrm{l})\end{array}$ & p-PI3K & p-Akt \\
\hline Blank & 0 & $\begin{array}{c}0.84 \pm \\
0.12\end{array}$ & $\begin{array}{c}0.46 \pm \\
0.06\end{array}$ \\
\hline Control & 30 & $\begin{array}{c}0.66 \pm \\
0.08^{\mathrm{a}}\end{array}$ & $\begin{array}{l}0.33 \pm \\
0.04^{\mathrm{a}}\end{array}$ \\
\hline $\begin{array}{l}\text { Low } \\
\text { ginsenoside }\end{array}$ & 60 & $\begin{array}{l}0.50 \pm \\
0.10^{\mathrm{ab}}\end{array}$ & $\begin{array}{l}0.27 \pm \\
0.03^{\mathrm{ab}}\end{array}$ \\
\hline $\begin{array}{l}\text { Medium } \\
\text { ginsenoside }\end{array}$ & 90 & $\begin{array}{l}0.28 \pm \\
0.04^{\mathrm{abc}}\end{array}$ & $\begin{array}{l}0.15 \pm \\
0.01^{\mathrm{abc}}\end{array}$ \\
\hline
\end{tabular}



Figure 1: Effect of ginsenoside at different concentrations on $\mathrm{p}-\mathrm{PI} 3 \mathrm{~K}$ and $\mathrm{p}-\mathrm{AKT}$ in MCF-7 cells
Effect of ginsenoside at different concentrations on ROS expressions in MCF-7 cells

There were markedly lower concentrations of ROS in ginsenoside-treated MCF-7 cells than in control group, and their levels decreased with increase in ginsenoside concentration $(p<0.05)$, as shown in Figure 2.
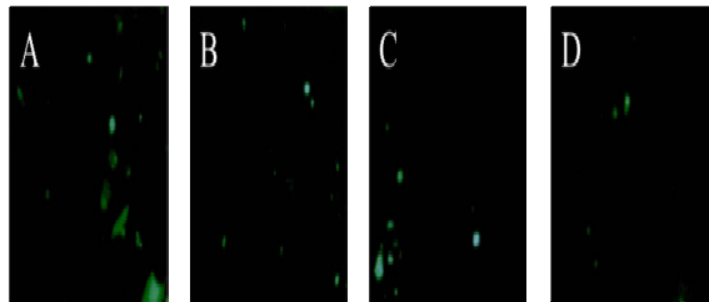

Figure 2: Influence of ginsenoside at different concentrations on ROS levels in MCF-7 cells. A: ROS expressions in MCF-7 cells in the control group; $\mathrm{B}$ : ROS in low ginsenoside group; C: ROS expressions in MCF-7 cells in the ginsenoside group, and D: ROS in high ginsenoside group

\section{DISCUSSION}

Studies have shown that variations in endogenous genetic susceptibility to breast carcinogenesis account for $20-25 \%$ of breast cancer incidence, while more than $70 \%$ of breast cancer is caused by long-term exposure to environmental factors, accounting for $7-10 \%$ of systemic tumors. The incidence of breast cancer is high among women aged 40 - 60 years (before and after menopause), and the incidence is on the rise $[8,9]$. At present, due to continuous progress in medical research, the treatment of breast cancer has improved, with chemotherapy as the most important treatment strategy after surgery and radiotherapy.

However, these treatments are often associated with undesirable side effects such as hair loss, vomiting, eating difficulties, pain, bone marrow suppression and drug resistance [10]. Therefore, it is necessary to evolve better treatment methods which can be used to achieve antitumor effects while improving the prognosis of patients [11]. Ginsenoside is the main active component of ginseng. Studies have shown that it inhibits tumor angiogenesis through inhibition of the proliferation and migration of vascular endothelial cells, inhibition of VEGF activity and its signal transduction pathway, and inhibition of the degradation of extracellular matrix [12].

The present study used different concentrations of ginsenoside to treat MCF-7 cells, and found 
that the $\%$ inhibition of MCF-7 cell proliferation in the control group did not change with time. However, the \% inhibition of cell viability was markedly higher in ginsenoside-exposed cells than in untreated cells, and it increased with time and ginsenoside concentration. The percentage of apoptosis in ginsenoside-treated MCF-7 cells was significantly higher than that in control group, and increased with increase in ginsenoside concentration. These results suggest that ginsenoside suppresses the viability of MCF-7 cells, and induces cell death in them.

It has been reported that ROS/PI3K/Akt signal route is vital for the regulation of cell viability [13]. The present study found that the enhancement of this signal route is among the causes of resistance of mammary cancer to hormone therapy. Studies have revealed that p-Akt, a serine/threonine protein kinase, p-PI3K (composed of regulatory p85 and catalytic subunits), and ROS (oxygen-containing chemically reactive molecules), promote breast cancer cell proliferation, increase cancer cell survival and tumorigenesis, and also promote angiogenesis, thereby enhancing metastasis of breast cancer cells.

Some researchers have reported that qinglongcoated polysaccharides directly inhibited or killed human colon cancer HCT-116 cells in vitro, through antitumor mechanisms related to ROS/PI3K/Akt signaling pathways [14-17]. In the present study, there were downregulations in $p$ Akt and $\mathrm{p}-\mathrm{PI} 3 \mathrm{~K}$ in ginsenoside-exposed MCF-7 cells, relative to control cells, and their levels decreased with increase in ginsenoside concentration.

The expressions of ROS in ginsenoside-exposed cells were markedly decreased, relative to control cells, and decreased with increase in ginsenoside concentration, suggesting that the inhibitory effects of ginsenoside on proliferation of MCF-7 cells, and its apoptotic effects might be associated with regulation of the ROS/PI3K/Akt signaling route.

\section{CONCLUSION}

These results show that ginsenoside decreases the viability of MCF-7 cells and induces their cell death via suppression of ROS/PI3K/Akt signaling pathway. Due to certain limitations, including the small number of samples used in this study, it was not possible to determine a clear relationship between ginsenoside and ROS/PI3K/Akt signaling route. This will be addressed in subsequent studies.

\section{DECLARATIONS}

\section{Acknowledgement}

This study was supported by Science and Technology Fundation of Tianjin Municipal Health and Health Committee (no. 2015KZ089), Anticancer Key Technologies R\&D Program of Tianjin (no. 12ZCDZSY16200), and Natural Science Foundation of Tianjin (no. 18JCYBJC91600).

\section{Conflict of interest}

No conflict of interest is associated with this work.

\section{Authors' contributions}

This study was done by the authors named in this article, and the authors accept all liabilities resulting from claims which relate to this article and its contents. The study was conceived and designed by Zhongsheng Tong; Lihong $\mathrm{He}$, Xiaorui Wang, Qing Ma, Weipeng Zhao, Yongsheng Jia, Guolei Dong, Yuehong Zhu, Xiaochen Jia and Zhongsheng Tong collected and analyzed the data while Lihong He wrote the manuscript. All authors read and approved the manuscript for publication.

\section{Open Access}

This is an Open Access article that uses a funding model which does not charge readers or their institutions for access and distributed under the terms of the Creative Commons Attribution License (http://creativecommons.org/licenses/by/ 4.0) and the Budapest Open Access Initiative (http://www.budapestopenaccessinitiative.org/rea d), which permit unrestricted use, distribution, and reproduction in any medium, provided the original work is properly credited.

\section{REFERENCES}

1. Rybicka A, Eyileten C, Taciak B, Mucha J, Majchrzak K, Hellmen E, Krol M. Tumour-associated macrophages influence canine mammary cancer stem-like cells enhancing their pro-angiogenic properties. J Physiol Pharmacol 2016; 67(4): 491-500.

2. Msaki A, Pastò A, Curtarello M, Arigoni M, Barutello G, Calogero RA, Macagno M, Cavallo $F$, Amadori $A$, Indraccolo $S$. A hypoxic signature marks tumors formed by disseminated tumor cells in the BALB-neuT mammary cancer model. Oncotarget 2016; 7(22): 33081-33095 
3. Telo S, Halifeoglu I, Ozercan IH. Effects of Stinging Nettle (Urtica Dioica L.) on Antioxidant Enzyme Activities in Rat Model of Mammary Gland Cancer. Iran J Pharm Res 2017; 16(Suppl): 164-170.

4. Song M, Du Z, LU G, Li P, Wang L. Syringic acid protects retinal ganglion cells against $\mathrm{H} 2 \mathrm{O} 2$-induced apoptosis through the activation of PI3K/Akt signaling pathway. Cell Mol Biol (Noisy-le-grand) 2016; 62(6): 50-54.

5. Xuan NT, Hoang NH, Nhung VP, Duong NT, Ha NH, Hai NV. Regulation of dendritic cell function by insulin/IGF1/PI3K/Akt signaling through klotho expression. J Recept Signal Transduct Res 2016; 37(3): 1-7.

6. Camp E, Anderson PJ, Zannettino ACW, Gronthos S. Tyrosine kinase receptor c-ros-oncogene 1 mediates TWIST-1 regulation of human mesenchymal stem cell lineage commitment. Bone 2016; 94: 98-107.

7. Yu N, Yang F, Leng $X$, Zhang N, Wang JY, Song N. LBP regulates PIBK/Akt/eNOS signaling pathways in ovariectomized rat myocardium to exert antioxidative effect. Chin J Pathophysiol 2016; 32(8): 1370-1375.

8. Pingwara R, Witt-Jurkowska K, Ulewicz K, Mucha J, Tonecka K, Pilch Z, Taciak B, Zabielska-Koczywas K, Mori $M$, Berardozzi $S$, et al. Interferon lambda 2 promotes mammary tumor metastasis via angiogenesis extension and stimulation of cancer cell migration. J Physiol Pharmacol 2017; 68(4): 573-583.

9. Nguyen NM, Andrade FO, Deassis S, Cruz I, Benitez C, Godschalk RWL, Hilakivi-Clarke L. Abstract 901: Transgenerational inheritance of increased mammary cancer risk in the offspring of high fat diet fed dams: Changes in oxidative stress pathways. Cancer Res 2016; 76(14):901.

10. Verma V, Vicini F, Tendulkar RD, Khan AJ, Wobb J, Edwards-Bennett S, Desai A, Shah C. Role of Internal
Mammary Node Radiation as a Part of Modern Breast Cancer Radiation Therapy: A Systematic Review. Int J Radiat Oncol Biol Phys 2016; 95(2): 617-631.

11. Cong BB, Qiu PF, Liu YB, Zhao T, Chen P, Cao XS, Wang $C J$, Zhang $Z P$, Sun $X$, Yu JM, et al. Validation study for the hypothesis of internal mammary sentinel lymph node lymphatic drainage in breast cancer. Oncotarget 2016; 7(27): 41996-42006.

12. Prasad A, Khudaynazar N, Tantravahi RV, Gillum AM, Hoffman BS. ON 01910.Na (rigosertib) inhibits PI3KJAkt pathway and activates oxidative stress signals in head and neck cancer cell lines. Oncotarget 2016; 7(48): 79388-79400.

13. Chen $X$, Zhao $X$, Cai $H$, Sun $H, H u Y$, Huang $X$, Kong $W$, Kong $W$. The role of sodium hydrosulfide in attenuating the aging process via PI3K/AKT and CaMKKB/AMPK pathways. Redox Biol 2017; 12: 987-1003.

14. Liu A, Wu J, Li A, Bi W, Liu T, Cao L, Liu Y, Dong L. The inhibitory mechanism of Cordyceps sinensis on cigarette smoke extract-induced senescence in human bronchial epithelial cells. Int J Chron Obstruct Pulmon Dis 2016; 11(1): 1721-1731.

15. Jin YQ, Li JL, Chen JD, Xu CL, Li H. Dalbergioidin (DAL) protects MC3T3-E1 osteoblastic cells against H2O2induced cell damage through activation of the PI3KJAKT/SMAD1 pathway. Naunyn Schmiedebergs Arch Pharmacol 2017; 390(7): 1-10.

16. Karaman S, Erturk $K$, Serilmez $M$, Duranyilidiz $D$, Oral EN, Dagoglu N. Serum AKT2 levels as a marker for lung cancer. Acta Med Mediterr 2019; 35(6): 3269-3272.

17. Guo CH, Zhang HF, Wen XM, Yun P, Li SY, Zhou YN. Tetramethylprazine mediates apoptosis of hepatocellular carcinoma cells through pi3k/akt signal pathway. Acta Med Mediterr 2019; 35(5): 2625-2628. 